\title{
Susceptibility to ergot in Zimbabwe of sorghums that remained uninfected in their native climates in Ethiopia and Rwanda
}

\author{
D. E. FREDERICKSON, P. G. MANTLE and W. A. J. DE MILliANO* \\ Department of Biochemistry. Imperial College of Science, Technology and Medicine. \\ London SW7 2AY, UK and ${ }^{*}$ Sorghum \& Millet Improvement Programme, SADC/ICRISAT, \\ PO Box 776, Bulawayo, Zimbabwe
}

Forty-four local Ethiopian and Rwandan sorghums (Sorghum bicolor) were observed to remain free of ergot, or had only low incidence, in their natural equatorial latitudes and were potentially of interest, in the design of male-sterile lines for $F_{1}$ hybrid breeding, if they possessed a physiologically based resistance mechanism. These sorghums were therefore also investigated under natural and artificial disease pressures in Zimbabwe where unadapted development and inappropriate long daylength prevented flowering in 18 accessions. Of the remaining 16 Ethiopian and $10 \mathrm{R}$ wandan accessions which flowered, only one from each country remained free of ergot. The susceptibility expressed was ascribed to observed asynchrony of stigma exsertion with anthesis. In the Rwandan accession that persistently remained free of ergot in Zimbabwe, histology of ovules showed pollination before floret gaping, so that a general principle of disease escape due to efficient pollination is proposed for the Ethiopian and Rwandan sorghums in their native climates. The findings emphasize that cleistogamy is a desirable character for avoiding ergot infection in self-fertile sorghums and suggest that the Ethiopian and Rwandan sorghums may not generally be useful for breeding ergot-resistant male-sterile female lines. However, a few accessions deserve more detailed study as a potential genetic resource, before a firm conclusion that all apparent resistance is disease escape owing to efficient pollination.

\section{INTRODUCTION}

Ergot disease of sorghum (Sorghum bicolor) was first reported in southern Africa in Tanganyika by Mason (1926). Although the pathogen has been generally known by its imperfect designation (Sphacelia sorghi McRae), and assumed to be included within Claviceps sorghi Kulkarni, Seshadri and Hegde (Bandyopadhyay, 1992), the disease is caused in Africa by Claviceps africana Frederickson, Mantle and De Milliano (Frederickson et al., 1991). Ergot disease of sorghum is an important constraint on $F_{1}$ hybrid seed production in southern Africa (Anon., 1992) where sclerotia of the fungus are formed at many locations (De Milliano, 1992). Exploitation of male-sterile female parents (A-lines) used in the sorghum seed production process is seriously threatened by annual outbreaks of ergol and the consequent reduction in both seed yield and quality to below economic thresholds. C. africana is widely endemic in Africa and is distinctly different, in several mycological and biochemical characteristics, from $C$. sorghi which is apparently confined to the Indian subcontinent (Frederickson et al., 1991). The pathogen in Thailand (Boon-Long, 1992). which has seriously constrained $F$, hybrid sorghum breeding, seems to be most like $C$. africana (Frederickson et al., 1991), but in Japan (Kimigafukuro, 1992) appears, from examination of the pathogen (and personal communication with $T$. Tsukiboshi), to be quite different from either $C$. sorghi or C. africana.

Control of ergot disease of sorghum through pollen management is envisaged, utilising efficient pollination of the A-line ovary to prevent infection. However, in Africa some sorghum landraces of Ethiopian and $\mathbf{R}$ wandan origin were observed to remain free from ergot (presumed to be $C$. africana) or to have significantly lower infection incidence of spikelets, after artificial inoculation in their natural environment. even after careful inoculations (Bandyopadhyay. 1992). They thereforc appeared in prospect to offer alternative control through sorghum bried- 
ing (Hulluka, 1982; ICRISAT, 1990) if an as yet unrecognized physiological mechanism was operating in this pool of local sorghums. Consequently, arising from preliminary screening by the International Crops Research Institute for the Semi-Arid Tropics (Bandyopadhyay, 1992), 44 selected sorghum accessions were grown in $\mathrm{Zim}$ babwe in the 1990/91 season to identify those that would flower in this environment. Twenty-six of the accessions that flowered in Zimbabwe were then subjected to natural and/or artificial disease pressures. The plantings provided an opportunity to observe susceptibility to the local pathogen ( $C$. africana) and further, by electron microscopy, to explore persistent escape from disease. The 1991/ 92 drought in southern Africa and the reduced prioritization as a result of the present findings, because of only long-term economical prospects and the high risk nature of the research, has precluded replication and extension of the findings.

\section{MATERIALS AND METHODS}

Nine of the Ethiopian accessions that flowered in Zimbabwe had been planted at two ecologically similar experimental stations (Henderson and Panmure, 30 and $100 \mathrm{~km}$ north of Harare, respectively) where Claviceps africana epiphytotics have occurred in recent years (Mtisi, 1992). Another seven accessions were planted only at Panmure. Ten Rwandan accessions were planted only at Henderson. The two locations were chosen also for their more predictable rainfall pattern, enabling early planting and minimizing mid-season water stresses. Planting was on 14 and 17 November 1990 for Ethiopian material at Henderson and Panmure, respectively, and 27 November 1990 for the Rwandan material. Ethiopian sorghums were seeded in two to six $5 \mathrm{~m}$ rows, whereas $R$ wandan accessions, limited by availability of seed, were sown in plots of two $5 \mathrm{~m}$ rows.

The experiment at Panmure relied entirely on natural disease pressure which was expected to be mainly due to airborne secondary conidia as inoculum (Frederickson el al., 1993). Before experimental sorghums flowered, ergot was abundant in a large area of other sorghum $A$-lines immediately adjacent. Since honeydew exudation was profuse and secondary conidiation (Frederickson et al., 1989) clearly evident, the A-lines were regarded as a source of inoculum for the Ethiopian sorghums, which commenced flowering only in late March 1991. At harvest, in late
June 1991, symptoms of ergot (sclerotia, and honeydew) were often masked by saprophytic Cerebella sp., which made it difficult to make more than a conservative estimate of the occurrence of ergot in each row of each accession.

At Henderson all experiments were under artificial disease pressure imposed by spraying suspensions of macroconidia (Frederickson et al., 1989). Flowering was delayed in those Ethiopian and Rwandan sorghums which eventually flowered until late March or early April 1991, most panicles having been in boot for a protracted period of about 4 weeks. As soon as individual panicles of each accession commenced anthesis, the first anthesing florets at the tip of the inflorescence were excised and the panicle was bagged. The following morning bagged individuals (usually 5, but up to 16 , per row) were inspected, and representative freshly anthesing forets, and as yet unopened adjacent florets, were excised and fixed in $2.5 \%$ glutaraldehyde in cacodylate buffer prior to preparation for electron microscopy (Frederickson \& Mantle, 1988). The glumes of other freshly anthesing florets were marked with ink. General floral characteristics and flowering behaviour were also noted. Finally, the panicle was inoculated by spraying until run-off with a fresh opaque aqueous suspension of ergot conidia prepared from diluted honeydew. The infectivity of the inoculum was tested in a similar manner at anthesis on five other very late-planted ICRISAT sorghum varieties which were known to contract the disease.

Marked florets were sampled $24 \mathrm{~h}$ post-inoculation for microscopy. Plants were scored for ergot disease 25 days post-inoculation, counting the proportion of infected panicles (disease incidence) and scoring the marked florets which were infected in each panicle (disease severity).

Histological preparation of gynoecia involved direct squashes in $1 \%$ neutral red in $45^{\circ}$ " acetic acid to detect pollen tubes. or in $0.1 \%$ cotton blue in lactophenol to detect hyphae of the pathogen. Subsequent transmission electron microscopy (Frederickson \& Mantle. 1988) sought specific evidence of pollen tubes in ovaries and particularly in the micropylar region.

\section{RESULTS}

All 26 of the Ethiopian and Rwandan sorghums grown in Zimbabwe. and which eventually flowcred. exhibited photoperiod-sensittvity and flowered only after a protracled period of vegetative growth, resulting in very tall ( $5 \mathrm{~m}$ ) phenotypes with long internodes. 
Table 1. Ergot disease and floret fertility in Ethiopian and Rwandan sorghums subjected to artificial disease pressure in Zimbabwe

\begin{tabular}{|c|c|c|c|c|c|}
\hline \multirow[b]{2}{*}{$\begin{array}{l}\text { Sorghum } \\
\text { accession }\end{array}$} & \multicolumn{3}{|c|}{ Artificial disease pressure (Henderson) } & \multicolumn{2}{|c|}{$\begin{array}{c}\begin{array}{c}\text { Floret fertility } \\
\text { (percentage pollination) }\end{array} \\
\end{array}$} \\
\hline & $\begin{array}{c}\text { disease } \\
\text { incidence } \\
(\%)\end{array}$ & $\begin{array}{l}\text { mean disease } \\
\text { severity }{ }^{b} \\
(\%)\end{array}$ & $\begin{array}{c}\text { seed set } \\
(\%)\end{array}$ & $\begin{array}{c}\text { before } \\
\text { anthesis }\end{array}$ & $\begin{array}{c}\text { in } \\
\text { anthesis }\end{array}$ \\
\hline \multicolumn{6}{|l|}{ Ethiopian } \\
\hline ETS 3252 & 0 & $\mathbf{0}$ & $\mathbf{0}$ & & \\
\hline ETS 3251-1 & 20 & 1 & 8 & 0 & $13-70$ \\
\hline ETS 4145 & 0 & $\mathbf{0}$ & 80 & & \\
\hline ETS 4457 & 47 & 2 & 34 & 0 & 50 \\
\hline ETS 4927 & 0 & 0 & 100 & & \\
\hline ETS 2448 & 50 & 1 & 11 & & \\
\hline ETS 3125 & 0 & $\mathbf{0}$ & 8 & & \\
\hline ETS 3912 & 0 & $\mathbf{0}$ & 0 & & \\
\hline ETS 1446 & 0 & $\mathbf{0}$ & 1 & & \\
\hline \multicolumn{6}{|l|}{ Rwandan } \\
\hline IS 25542 & 50 & 8 & 0 & 0 & 78 \\
\hline IS 25576 & 100 & 4 & 0 & 10 & 19 \\
\hline IS 25555 & 75 & 5 & 81 & 33 & 93 \\
\hline $83 / 8 / 1 / 1$ & 50 & 3 & 23 & 0 & 16 \\
\hline $83 / 54 / 4 / 2-2$ & 60 & 2 & 68 & 0 & 65 \\
\hline $83 / 54 / 1 / 2$ & 50 & 3 & 18 & 0 & 22 \\
\hline $83 / 42 / 1 / 1$ & 17 & 1 & 85 & 35 & \\
\hline 12192 & 30 & 1 & 92 & 0 & 40 \\
\hline TURA & 66 & 1 & 99 & 50 & 90 \\
\hline IS 25485 & 0 & 0 & 100 & 44 & 100 \\
\hline
\end{tabular}

accession which became ergotized under natural disease pressure at Panmure.

${ }^{b}$ Percentage of the florets inoculated at anthesis that became diseased.

The sorghum varieties used at Henderson to determine the pathogenicity of the artificial inoculum all became infected and showed a mean disease incidence of $64 \%$ and mean disease severity of $16 \%$, confirming a potentially infective inoculum.

Under natural disease pressure at Panmure, only one of the 16 Ethiopian accessions (ETS 1446, five rows) failed to become infected with ergot. In the other 15 accessions, 8 expressed the disease in all rows (ETS 2518, 3215, 3251-1, 3252, $4145,4145-1,4145-2,4145-3$ ) and, in the other 7 , inflorescences in one to five rows out of two to six were diseased (ETS 2448, 2465, 3125, 3912, 4145. 4, 4457, 4927).

Artificial inoculation at Henderson caused the disease on 12 of the 19 Ethiopian and Rwandan sorghums tested (Table 1). Whereas the incidence was often quite high, sometimes higher than in the varieties used for a quality test on the inoculum. severity was generally low. However, five of the six Ethiopian sorghums which were free from ergot disease in the experiment at Henderson research station contracted the disease from natural sources at Panmure. Therefore, of the 26 sorghums in the experiment, only two, one each from Ethiopia (ETS 1446) and Rwanda (IS 25485), remained ergot-free in Zimbabwe.

Staining of gynoecia with cotton blue, $24 \mathrm{~h}$ post-inoculation, verified the presence of conidia on stigmas of all Ethiopian and $\mathbf{R}$ wandan sorghums at Henderson. Some conidia were already germinating. However, Rwandan IS 25485 had additionally an abundance of germinated pollen on stigmatic hairs at this time, pollen tubes having penetrated the stigma and residual pollen grains appearing slightly collapsed (Fig. 1). Examination of florets collected at the same time. though developmentally still about 1 day pre-gaping. showed that cleistogamous pollination had already occurred in $44 \%$ of IS $254 k 5$ florets. The floral cavities were full of pollen, anthers having 


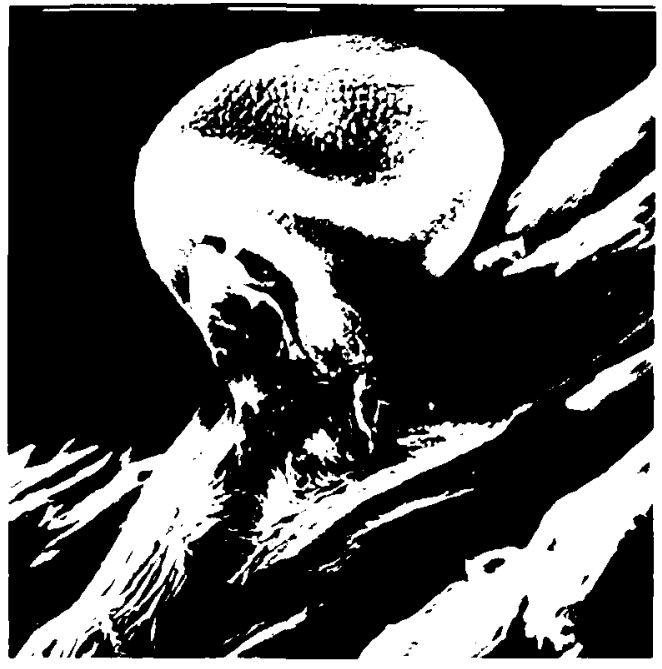

Fig. 1. A stlgmatc hair of Rwandan sorghum accession IS $254 \times 5$ penetrated hy germmated pollen gram 24 hoursafter floret gaping (White barsat top of figure $10 \mu \mathrm{m}$.)

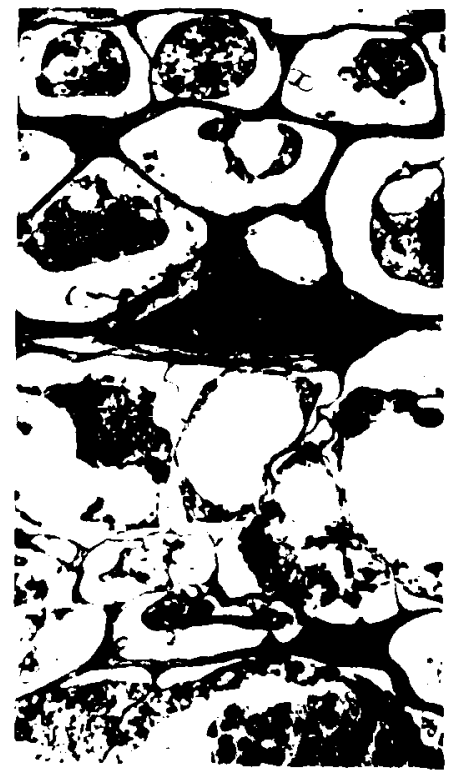

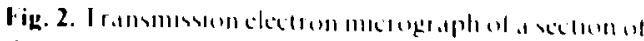

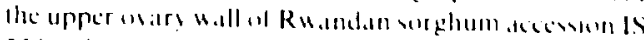

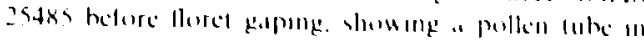

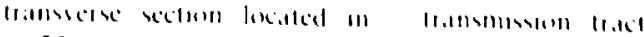
1. $25(10)$

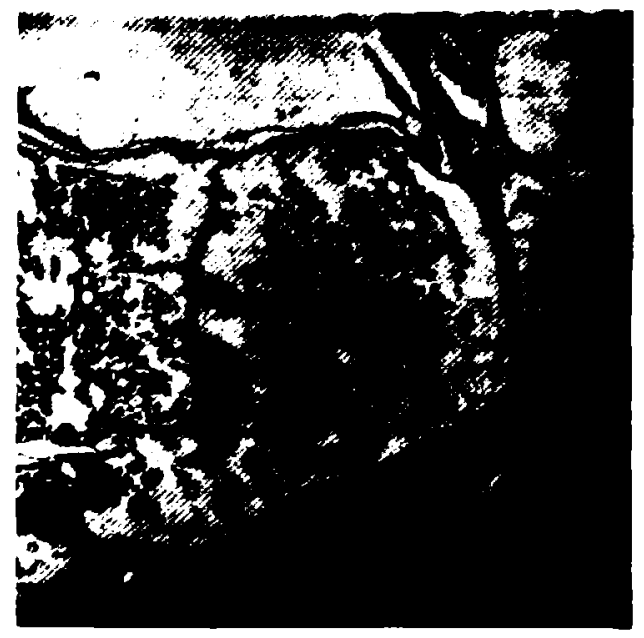

Fig. 3. Transmission electron micrograph of a near median longitudinal section through the proximal end of an ovule of Rwandan sorghum accession IS 25485 24 hours alter floret gapung. The egg apparatus (centre) is hounded to the right and below by nucellar cells. The vace d toplefts the central cell. A pollen tube adjacent to the proximal aspect of the egg apparatus is shoun magnitied in Fig +1 . 1900)

already dehisced. and pollen tuhes were progressing down the styles. Longitudinal sections revealed intercellular pollen tubes as far as the top of the ovary (Fig 2). some interposed between the innermost tissues of the ovary wall and the ovule. When IS 25485 florets gaped. stlgma exsertion could be expected, but it did not happen. All these forets were already self-pollinated At $24 \mathrm{~h}$ postincculation. when spores had only just germinated. a pollen tuhe was recognized. by electron microscopy. in the micropylar region of an ovary and within the micropylar cuticle reaching a position immediately everior to the embryosac. in the matrix-filled space adjacent to the egg cell (Figs 3 and 4). The proumity of the pollen tute indicaled that fertilization was imminent in IS 25485 il it had not alreads occurred

A umblar floral hoolong was observed in the Ruandan TURA: $50^{\prime \prime}$ "of the florets were cleistogimous and. following further self-pollination at anthess. a large proportion of plorets had been pollinatcd hetorecergot inoculum could germinate (1) vegmas Alehough a high incidence $\left(66^{\prime \prime}\right.$ ) of "rget resulted. the 49". secd set ensured that the weril! uas low Fertule pedicelled spikelets may aloo hate increased the pollen pressure

In contrast to IS 25485 and TURA, ergot in IS 25570 reilched $1(10) "$ incidence. Interestingly, 


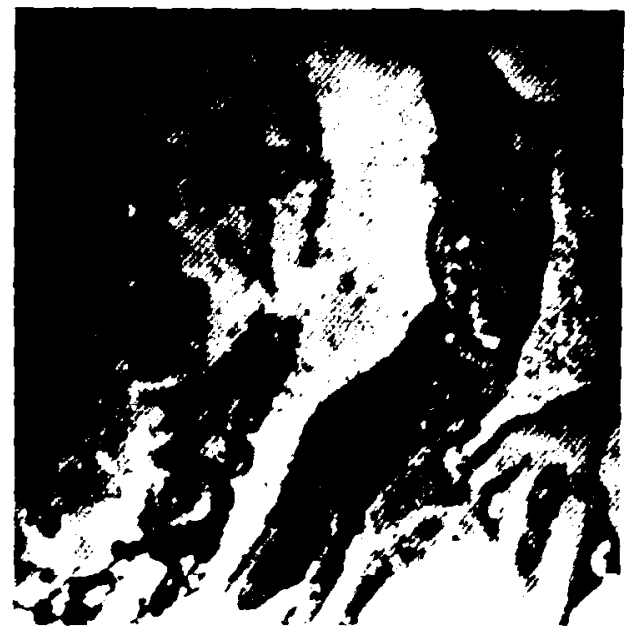

Fig. 4. Transmission electron micrograph of a section of the proximal region of the ovule illustrated in Fig. 3. and orientated similarly, showing the lateral edge of the egg apparatus (left) and pollen tube with dense cytoplasm (right) immediately exterior to the ambryo sac. Imminent fertilization is implied $(\times 7100)$

although pollination and seed set were low. crgot severity was also low. Conidia were, however. viable, observed germinating on stigmas $24 \mathrm{~h}$ post-inoculation. Often, $48 \mathrm{~h}$ post-inoculation. styles of IS 25570 exhibited a necrotic spotting reaction at the mid-point, progressing to a uniformly necrotic region a day later so that some stigmas fractured. This necrosis may have served to limit invasion of the fungus down the style of a fertilized ovary, although it could also likewise hinder passage of the pollen tube when an ovary is infected by $C$. africana. Other accessions were intermediate in nature, exhibiting lesser degrees either of cleistogamy or of the necrotic reaction (ETS 3251-1; ETS 4457).

\section{DISCUSSION}

Integration of the results of natural and artificial inoculation of Ethiopian and Rwandan sorghums, reputed to be resistant to crgot at least in their country of origin, has shown that, in all except two, gynoecia could become parasitized by C. africana under the conditions of this experiment. Even in this somewhat unnatural environment, in which their growth habit was altered, flowering behaviour of the apparently resistant accessions still ensured sufficient self-pollination to exclude the ergot pathogen from most of the florets. Indeed, the Rwandan IS 25485 was so efficient by selfing before gaping that it completely escaped infection. It is concluded, from consideration also of the histological evidence and that of the observations on flowering behaviour, that at least most of the accessions tested had no special gynoecial physiology which prevented ergot parasitism. The resistance expressed in their natural environment will result from efficient self-pollination, allowing insutficient time for colonization of the ovary by the slower pathogen. However. the local necrotic reactions in stigmas of three accessions in particular may be somewhat analogous to that in pearl millet (Willingale $e^{2}$ al. 1986), although necrosis would still not exclude the pathogen if the fungus had entered the ovary first.

The simple circumstances of the experiment cannot sustain 100 much comparison of the results of natural and artificial disedse pressures. Nevertheless. the accurrence of ergol in the Ethiopian sorghums under natural divease pressure at Panmure illustrates hou readily disease spreads naturally. It also raises the possibility. for example. that first gaping floret at night. giving access to a few alrhorne secondary conidlat ats inoculum. may hale become infected hefore pollination. whereas sprayng a much more concentrated inoculum into gaping florets later the next day as happened in experiments at Henderson. failed. However, there is still the possibilit! that accession ETS $1+46$ (provided by the Ethiopian Sorghum Improvement Programmel may be of interest. Although it hardly set seed. it still failed to become infected. Possible explanitions could be that gynocial formation was abnormal in the changed enuronment or that ga noecla were unreceptive in this environment smilarly hoth to pollen and pathogen as stlgma-mbiding filaments. However the finding concerning the accession might justify a moreconcerted effort to explore pre-fertulezation gynocelal sumcepubility to C. alricama in Ethiopla before beng sure it has no value

It appears that some fundamental structural or physological gynocial character. not diredly involved in pollination and ferulizalien. that would exclude the ergot fungum and could be incorporated into clate A-lines, does note exent in the accessoons which flowered in the present study, as is apparent concernong all other ergon host interactions The only character thate effects freedom from ergat in a parlicular grammiccous host concerns efficient pollinillon fertilistloon and therefore constluter a deacise excape mechanısm 
However, further search for intrinsic gynoecial resistance to ergot in sorghums is warranted before excluding such as a potentially exploitable heritable character. Chemically induced male sterility may aid the exploration of gynoecial susceptibility in sorghums which naturally escape ergot when in their native latitude or when induced to flower in more convenient experimental environments. Nevertheless, the consistently low ergot severity despite artificial inoculation of the accessions described here, combined with some instances of high seed set, is an encouraging finding. However, if potentially useful resistance to ergot disease is found in sorghums, the diversity of pathogens in Africa and Asia will require multilocational testing of potential cultivars.

\section{ACKNOWLEDGEMENTS}

This research, in London and Bulawayo, has been supported by the UK Overseas Development Administration. The seed was provided through kind assistance of V. Guiragossian (ICRISAT Eastern Africa), R. Bandyopadhyay (ICRISAT Centre), the SADCC/ICRISAT Sorghum and Millet Improvement Programme, Bulawayo. Zimbabwe, the Ethiopian Sorghum Improvement Programme and the Rwandan Crop Improvement Programme. Mrs E. Mtisi and J. Benza, of the Department of Research and Specialist Services, Harare, Zimbabwe, are thanked for their support of, and assistance in, the research.

\section{REFERENCES}

Anonymous, 1992. Recommendations concerning sorghum ergot. In: Sorghum and Millets Diseases: A Second World Review. Patancheru, India: International Crops Research Institute for the Semı-Arid Tropics. 335-6.

Bandyopadhyay R. 1992. Sorghum ergot. In: Surghum and Millets Diseases: A Secund World Revien: Patancheru, India: International Crops Research Institute for the Semi-Arid Tropics, 235 4
Boon-Long T, 1992. Sorghum diseases in Thailand. In: Sorghum and Millets Diseases: A Second World Review: Patancheru, India: International Crops Research Institute for the Semi-Arid Tropics, 41-3.

De Milliano WAJ, 1992. Sorghum diseases in southern Africa. In: Sorghum and Millets Diseases: A Second World Revien: Patancheru, India: International Crops Research Institute for the Semi-Arid Tropics, 9-19.

Frederickson DE, Mantle PG. 1988. The path of infection of sorghum by Claviceps sorghi. Physiological and Molecular Plant Pathology 33, 221-34.

Frederickson DE, Mantle PG, De Milliano WAJ, 1989. Secondary conidiation of Sphacelia sorghi on sorghum. a novel factor in the epidemiology of ergot disease. Mycological Research 93, 497-502.

Frederickson DE, Mantle PG, De Milliano WAJ, 1991. Claviceps africana sp. nov.; the distinctive ergot pathogen of sorghum in Africa. Mycological Research 95, 1101-7.

Frederickson DE, Mantle PG, De Milliano WAJ, 1993. Windborne spread of ergot disease (Claciceps africana) in sorghum A-lines in Zimbabwe. Plant Patho$\log y$ 42, 368-77.

Hulluka M, 1982. Diseases of sorghum at some locations in Ethiopia. Ethiopian Journal of Agricultural Science 4, 45-53.

ICRISAT, 1990. Report. Patancheru, India: International Crops Research Institute for the Semi-Arid Tropics.

Kimigafukuro T, 1992. Sorghum and sorghum diseases in Japan. In: Sorghum and Millers Diseases: A Second "1 orld Review. Patancheru. India: International Crops Research Institute for the Semi-Arid Tropics. 3I-4.

Mason EW, 1926. On two copies of Tolyposporiven Woronin recorded on cultivated sorghum. Transactions of the British Mycological Society 11, 284-6.

Mtisi E, 1992. Sorghum and pearl millet pathology in Zimbabwe. In: Sorghum and Millets Diseases: A Second W'orld Reviell Patancheru. India: International Crops Research Institute for the Semi-Arid Tropics, 3-7.

Willıngale J. Mantle PG. Thakur RP, 1986. Postpollination constriction. the basis of ergot resistance in selected lines of pearl millet. Phytopathology 76. 536-9. 
This document is a scanned copy of a printed document. No warranty is given about the accuracy of the copy. Users should refer to the original published version of the material. 